\title{
Triacetate of Benzoazacrown Compound as a Chelator for Lead Cations Promising for Targeted Radiopharmaceuticals
}

\author{
Bayirta V. Egorova, ${ }^{a}{ }^{@}$ Lyubov S. Zamurueva $_{1}{ }^{a}$ Anastasia D. Zubenko, ${ }^{\text {b }}$ \\ Anna V. Pashanova, ${ }^{\text {b,c }}$ Zeena S. Pillai, ${ }^{d}$ Olga A. Fedorova, ${ }^{\text {b,c }}$ \\ and Stepan N. Kalmykov
}

\author{
${ }^{a}$ Lomonosov Moscow State University, 119991 Moscow, Russian Federation \\ b A.N. Nesmeyanov Institute of Organoelement Compounds of Russian Academy of Sciences, 119991 Moscow, Russian \\ Federation \\ 'D.I. Mendeleev University of Chemical Technology of Russia, 125047 Moscow, Russian Federation \\ ${ }^{\mathrm{d}}$ Department of Chemistry, Amrita School of Arts and Sciences, 682024 Kerala, India \\ ${ }^{\circledR}$ Corresponding authorE-mail: bayirta.egorova@gmail.com
}

\begin{abstract}
Triacetate of 15-benzoazacrown-5 compound $\left(H_{3} B A 3 A\right)$ is a new ligand that has shown advantages towards chelation of some cations. In this paper $\mathrm{H}_{3} B A 3 A$ was consequently studied for binding of lead cation. With respect to nuclear properties of ${ }^{212} \mathrm{~Pb}$ radioisotope it can be used for therapy of various oncological diseases mainly due to alpha-emitting daughter radionuclide ${ }^{212} \mathrm{Bi}$. Complexes of such radionuclides are considered as parts of targeted radiopharmaceuticals that can be conjugated with biomolecules to provide address delivery to cancerous tissues. Medical radionuclides are commonly short-lived and biomolecules are often heat-sensitive. That is why fast and stable complexation of trace amounts of lead cations in biologically relevant media without additional heating higher than $37{ }^{\circ} \mathrm{C}$ is important and challenging task. At the beginning we determined complexation constants in wide pH range including different protonated and hydrolyzed complex species via potentiometric titration technique. The obtained values are high enough for lead chelates $\log \beta\left(B A 3 A P b^{-}\right)=17.2$ (1). Structural features of complex in aqueous solution were established due to ${ }^{1} \mathrm{H}$ and ${ }^{13} \mathrm{C} N \mathrm{NM}$ spectroscopy. High resolution of obtained spectra and comparison with spectrum of deprotonated ligand shows presence of one rigid conformer of complexed form in the aqueous solution with $C_{s}$ symmetry. In order to study labelled compounds we used longer lived isotope of lead ${ }^{210} \mathrm{~Pb}$ isolated from solution of ${ }^{226} \mathrm{Ra}$. Using thin layer chromatography and gamma-spectrometry it was found that $100 \mu \mathrm{M}$ of ligand is enough to completely chelate ${ }^{210} \mathrm{~Pb}$ in the tracer concentration related to radiopharmaceutical concentration of ${ }^{212} \mathrm{~Pb}$. According to $\mathrm{pH}$ speciation obtained in complexation constant determination, pH 5.5-6 was selected for labelling experiments. Noteworthy, the labeled compound was obtained within 1-5 minutes at room temperature as well as upon heating at $90{ }^{\circ} \mathrm{C}$. Macrocyclic $\mathrm{H}_{3} \mathrm{BA3} \mathrm{A}$ demonstrates fast complexation apparently due to larger crown cavity compared to cyclen cavity in $H_{4} D O T A$. This was indirectly shown in potentiometric titration where waiting time for curve's points was no longer than 5 minutes indicating that equilibrium was achieved within 5 minutes. In order to evaluate possible trans-chelation and transmetallation of complex in living organism we performed challenging experiments in static conditions: in presence of nine-fold excess of serum proteins, biologically relevant cations $5 \mathrm{mMCa^{2+ }}, 5 \mathrm{mM} \mathrm{Mg^{2+ }}, 0.1 \mathrm{mM} \mathrm{Zn}^{2+}, 0.1 \mathrm{mM} \mathrm{Cu}^{2+}$, $0.1 \mathrm{mM} \mathrm{Fe} e^{3+}$ and isotonic solution of $0.15 \mathrm{M} \mathrm{NaCl}$. It was shown that the $100 \%$ intactness of complex can be kept for up to two days of incubation in competing media. Summarizing, the $\mathrm{H}_{3} \mathrm{BA} 3 \mathrm{~A}$ forms highly stable complex with lead cation not only in model solution, but also in presence of challenging agents. This stability is provided by high stability constants and rigid structure in solution.
\end{abstract}

Keywords: Benzoazacrown, lead-212, complexation constants, in vitro stability, radiopharmaceutical, targeted delivery. 


\title{
Триацетат бензоазакраун-соединения в качестве хелатора катионов свинца в составе таргетного радиофармпрепарата
}

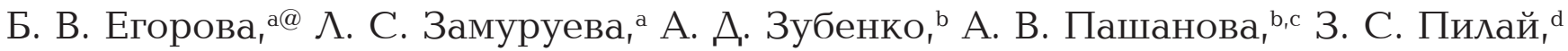 \\ О. А. Федорова, ${ }^{\text {b,c }}$ C. Н. Калмыков ${ }^{\mathrm{a}}$
}

${ }^{\mathrm{a}}$ Московский государственньй университет им. М.В. Ломоносова, 119991 Москва, Россия

${ }^{\mathrm{b}}$ Институт элементоорганических соединений РАН им. А.Н. Несмеянова, 119991 Москва, Россия

'Российский химико-технологический университет им. Д.И. Менделеева, 125047 Москва, Россия

${ }^{\mathrm{d}}$ Кафедра химии, Школа искусств и наук, 682024 Керала, Индия

${ }^{\circledR}$ E-mail: bayirta.egorova@gmail.com

\begin{abstract}
В работе изучено комплексообразование триацетата 15-бензоазакраун-5 соединения (НЗВАЗА) с катионом свинца в водном растворе. Методом потенциометрического титрования определень константы устойчивости различных протонированных и гидроксидных комплексных форм. Полученные значения достаточно высоки для комплексов свинща. Согласно ${ }^{1} \mathrm{H}{ }^{13} \mathrm{C}$ ЯМР спектроскопии в растворе при рН 7 образуется один жёсткий конформер комплекса с симметрией $C_{s}$. Для оценки возможности получения комплекса с радионуклидом свинца был получен меченный изотопом ${ }^{210} \mathrm{~Pb}$ комплекс $\left[{ }^{10} \mathrm{~Pb}\right] \mathrm{PbBA3A}$ и изучена его устойчивость в различных средах биологического значения: в присутствии девятикратного избытка сывороточных белков, катионов микроэлементов и изотоническом растворе. Согласно полученным результатам образование меченного соединения происходит в течение первых 1-5 минут взаимодействия при комнатной температуре, что говорит о быстром комплексообразовании, важном при использовании короткоживущих медицинских радионуклидов. Для синтеза меченого соединения могут быть использованы ацетатный и фосфатный буферные растворы. Полученные меченные соединения демонстрируют высокую диссоииативную устойчивость к перехелатированию и трансметаллированию даже при инкубации в конкурентной среде в течение 2 суток.
\end{abstract}

Ключевые слова: Бензоазакраун, свинец-212, константы комплексообразования, in vitro устойчивость, радиофармпрепарат, таргетная доставка.

\section{Introduction}

Nowadays, targeted alpha therapy is one of the most promising methods for treatment of oncological diseases. Especially in the case of tumors and metastatic formations of small size, alpha radiation is the most local and, accordingly, effective due to the low linear energy transfer.

The short-lived bismuth isotopes ${ }^{212,213} \mathrm{Bi}$ with halflives of 61 and $46 \mathrm{~min}$ respectively have already demonstrated their therapeutic perspective, however, the use of their parent radionuclides ${ }^{212} \mathrm{~Pb}$ and ${ }^{225} \mathrm{Ac}$ seems to be more promising due to the longer half-life. ${ }^{[1]}$ Radioisotope ${ }^{212} \mathrm{~Pb}$ itself is a beta emitter and applied as a radiopharmaceutical acts as an in vivo generator of alpha emitting ${ }^{212} \mathrm{Bi}$.

One of the main concepts at the moment is the creation of an radiopharmaceutical based on targeted molecules labeled with a specific radionuclide. Monoclonal antibodies, their fragments or peptides having an affinity for certain tumor cells are used as a target molecule. Due to the high toxicity of alpha radiation, it is important to maintain the intactness of the labeled compound in vivo. In the case of radiometals radiopharmaceutical contains a bifunctional chelating agent, which, on the one hand, is covalently bound to the biomolecule, and, on the other hand, forms a stable coordination compound with the radionuclide cation. Tra- ditionally, polyaminopolycarboxylates of the macrocyclic or acyclic type are used as such chelating agents. Moreover, it is the macrocyclic ligands that form the most stable in vitro and in vivo complexes. However, the high inertness of the complexes formed is accompanied by a slow cation binding reaction, which, in the case of short-lived medical radionuclides, can lead to significant activity losses during the production of radiopharmaceuticals. Thus, heating up to $100{ }^{\circ} \mathrm{C}$ is used to accelerate the labeling reaction, but this option is unacceptable for conjugates of heat-sensitive biomolecules. The latter are labelled via acyclic ligands - derivatives of diethylenetriaminepentaacetic acid, which form complexes within a few minutes at room temperature, but under in vivo conditions there is a high probability of dissociation of such complexes, release of a radionuclide,

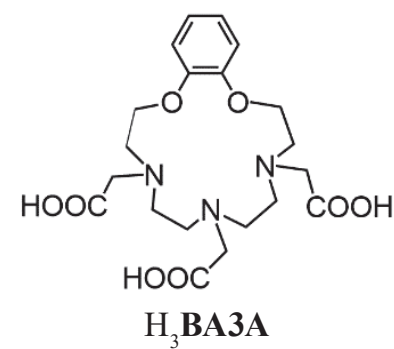


its accumulation and consequent irradiation of healthy tissues. One of the ways to solve this problem is to combine the approaches of acyclic and macrocyclic ligands. At the moment, the use of functionalized additional chelating groups on the macrocycle of cyclene is the most common approach in the literature. ${ }^{[1,2]}$

Recently, we have shown that triacetate of benzoazacrown ether $\mathrm{H}_{3} \mathbf{B A 3 A}$ can effectively bind cations of doublecharged cations $\mathrm{Cu}^{2+}$ and $\mathrm{Zn}^{2+} \cdot{ }^{23]}$ In this work, we attempted to evaluate from different points the potential of this ligand for therapeutic use with ${ }^{212} \mathrm{~Pb}$. On the other hand, in addition to the importance of binding the ${ }^{212} \mathrm{~Pb}$ radionuclide for therapy, chelation of lead cations in general has been of medical interest for a long time from the point of detoxification of the body in case of poisoning with heavy metals, including lead.

\section{Experimental}

The synthesis and characterization of $\mathrm{H}_{3} \mathbf{B A} \mathbf{3 A}$ have been described in detail previously. ${ }^{[3]}$

\section{Potentiometric Titration and Calculation of Stability Constants}

Potentiometric titration was performed using an 848 Titrino Plus autotitrator equipped with a $5 \mathrm{~mL}$ autoburette and Metrohm combined $\mathrm{pH}$ glass electrode (model 60262100). Titration with $\mathrm{HClO}_{4}$ was carried out in the same mode that is used to calculate the constants to determine the standard electrode potential $E$. The dependence of the solution potential on the amount of added alkali was obtained from the titration data and using the GLEE program (glass electrode evaluation) and the previously determined concentrations of $\mathrm{HClO}_{4}$ and $\mathrm{NaOH}$ the value of $E_{o}$ was determined.

To determine the complexation constants, titration of a $0.001 \mathrm{M}$ ligand solution was carried out with the addition of an equimolar amount of a $\mathrm{Pb}^{2+}$ solution and a $0.01 \mathrm{M} \mathrm{HClO}_{4}$ solution to lower the initial $\mathrm{pH}$. To maintain constant ionic strength during an experiment a solution of $0.1 \mathrm{M} \mathrm{KNO}_{3}$ was used as a background electrolyte; it was thermostated at $25{ }^{\circ} \mathrm{C}$ under flow of nitrogen (to minimize role of carbon dioxide).

The complexation constants were calculated using the HyperQuad2008 program using the hydrolysis constants, the ionic product of water and the preliminarily obtained $E_{o}$ value.

\section{Radiochemical Separation of ${ }^{210} \mathrm{~Pb}$}

Radiochemical separation of ${ }^{210} \mathrm{~Pb}$ using Sr-resin (Triskem Inc.) is described in the literature. ${ }^{[4]}$ Briefly, a solution of ${ }^{226} \mathrm{Ra}$ dissolved in $0.1 \mathrm{M} \mathrm{HNO}_{3}$ was loaded on a Sr-resin chromatographic column, a solution of $0.1 \mathrm{M} \mathrm{HNO}_{3}$ was passed through a column until the radium was completely rinsed, then ${ }^{210} \mathrm{~Pb}$ was washed off with $0.05 \mathrm{M}\left(\mathrm{NH}_{4}\right)_{3}$ cit. The separation of ${ }^{210} \mathrm{~Pb}$ from ${ }^{226} \mathrm{Ra}$ was monitored by using gamma spectrometry (high-purity germanium semiconductor detector, Canberra) at $46.5 \mathrm{keV}\left({ }^{210} \mathrm{~Pb}\right)$ and $186.2 \mathrm{keV}\left({ }^{226} \mathrm{Ra}\right)$ peaks. The resulting solution was evaporated and redissolved in $0.1 \mathrm{M} \mathrm{HCl}$.

\section{Radiolabeling Studies}

The complex was labeled at room temperature and upon heating to $90{ }^{\circ} \mathrm{C}$; a ${ }^{210} \mathrm{~Pb}$ solution was added to various buffers: $0.15 \mathrm{M} \mathrm{NaOAc}$ (sodium acetate), 0.15 M MES (2-( $N$-Morpholino) ethanesulfonic acid), and 0.1 M PBS (Phosphate buffered saline) and mixed with the ligand. Thin layer chromatography (TLC) was used to control the bound fraction of radionuclide. TLC experi- ments were performed using silica-impregnated glass fiber paper (Agilent iTLC plates) as a stationary phase and $10 \mathrm{mM} \mathrm{NaOH}$ dissolved in $0.9 \% \mathrm{NaCl}$ as an eluent. Analysis of the distribution of radioactivity on the plates was carried out using gamma spectroscopy. To select the optimal concentration of ligand, the ${ }^{210} \mathrm{~Pb}$ solution was mixed with the selected buffer $(0.15 \mathrm{M} \mathrm{NaOAc})$ and various concentrations of ligand; the determination of the yield of the complexation was carried out by the TLC method described above, followed by gamma spectroscopy of the TLC plates.

\section{Stability of $\left[{ }^{210} \mathrm{~Pb}\right] \mathrm{PbB} \boldsymbol{A} \mathbf{3} \boldsymbol{A}$ in Biological Systems}

The resulting complex with radiochemical purity $>95 \%$ was added to solutions of cations of microelements $\left(5 \mathrm{mM} \mathrm{Ca}^{2+}\right.$ and $\mathrm{Mg}^{2+}, 0.1 \mathrm{mM} \mathrm{Fe}^{3+}, \mathrm{Zn}^{2+}$, and $\mathrm{Cu}^{2+}$ ) and isotonic solution of $0.15 \mathrm{M}$ $\mathrm{NaCl}$. After 1 hour and 24 hours of incubation at $37^{\circ} \mathrm{C}$, the bound fraction of radionuclide was measured by TLC and gamma spectroscopy.

The complexes were also mixed with a nine-fold excess of fetal bovine serum (HyClone) and incubated at $37{ }^{\circ} \mathrm{C}$, then an aliquot of this solution was taken at fixed time points and the protein fraction was precipitated with an excess of ethanol, cooled to $2-4{ }^{\circ} \mathrm{C}$, centrifuged and the supernatant was separated. The content of radioactivity in the supernatant was established using gamma spectrometry. The experiment without an addition of ligand was carried out in the same conditions.

\section{NMR Spectroscopy}

${ }^{1} \mathrm{H}$ and ${ }^{13} \mathrm{C}$ NMR spectra were recorded in $\mathrm{D}_{2} \mathrm{O}$ at $25{ }^{\circ} \mathrm{C}$ on Varian Inova 400 spectrometer. Chemical shifts for ${ }^{1} \mathrm{H}$ and ${ }^{13} \mathrm{C}$ are reported in parts per million $(\delta)$ relative to deuterated solvent as an internal reference $\left(\mathrm{D}_{2} \mathrm{O} \delta=4.75\right)$. Coupling constants $(J)$ are given in hertz. Spectral assignments were based in part on the two-dimensional NMR experiments ( ${ }^{1} \mathrm{H}$ COSY and NOESY). To investigate the complexation of the ligands $\mathrm{H}_{3} \mathbf{B A 3} \mathbf{A}$ with $\mathrm{Pb}^{2+}$ cation in aqueous solutions, ${ }^{1} \mathrm{H}$ NMR spectroscopic study was carried out. Samples of the $\mathrm{Pb}^{2+}$ complexes for the NMR measurements were prepared by dissolving the corresponding ligand and 2 eq. $\mathrm{Pb}(\mathrm{ClO} 4)_{2}$ in $\mathrm{D}_{2} \mathrm{O}$, followed by adjustment of the desired $\mathrm{p} D$ with small volumes of concentrated $\mathrm{HClO}_{4}$ or $\mathrm{NaOH}$. The accurate $\mathrm{p} D$ measurements in $\mathrm{D}_{2} \mathrm{O}$ were obtained by direct reading in a $\mathrm{D}_{2} \mathrm{O}$ solution using combined glass $/ \mathrm{AgCl}$ electrode after appropriate calibration procedures by usage of standard buffers.

\section{Results and Discussion}

\section{Complexation in the $\mathrm{Pb}^{2+}-\mathrm{H}_{3} \boldsymbol{B} \boldsymbol{A} \mathbf{3} \boldsymbol{A}$ System}

One of the initial characteristics of coordination compounds is the determination of the stability constant of the complex compound. To do this we used the method of potentiometric titration. Under the same conditions in a similar way the protonation constants of this ligand were determined previously. ${ }^{\left[{ }^{[3]}\right.}$ According to the obtained values: $\log \beta(\mathrm{LHPb})=21.0(1), \log \beta(\mathrm{LPb})=17.2(1)$, $\log \beta(\mathrm{LPbOH})=23.1(1), \log \beta\left(\mathrm{LPb}(\mathrm{OH})_{2}\right)=26.3(1)-$ at lower $\mathrm{p} H$ values a complex with a monoprotonated form of the ligand is formed, then it deprotonates to the $\mathrm{LPb}$ form, and at $\mathrm{pH}>8, \mathrm{LPb}(\mathrm{OH})_{\mathrm{n}}$ hydroxide complexes are formed (Figure 1). Noteworthy that in opposite to the previously studied precursors of the ligand $\mathrm{H}_{3} \mathbf{B A} \mathbf{B A}{ }^{[5]}$ the formation of insoluble lead hydroxides was not observed in the entire studied $\mathrm{p} H$ range $2.5-11$. This fact indicates a significantly higher stability of the complex with this ligand due 


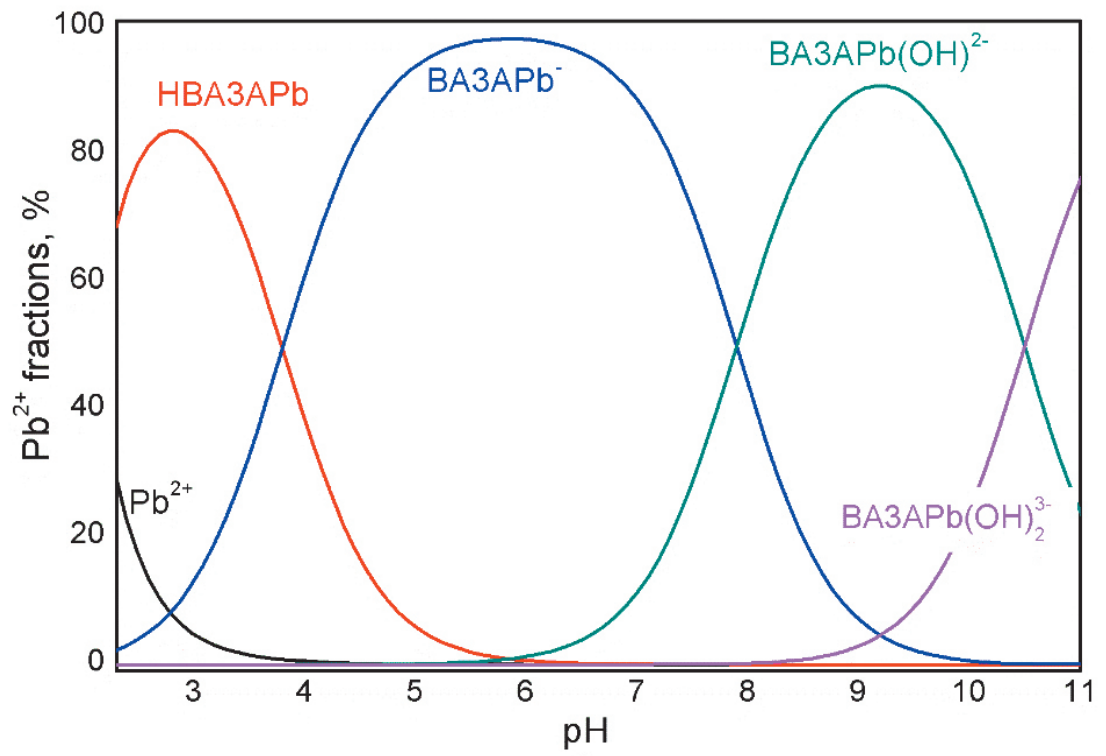

Figure 1. Distribution of the $\mathrm{Pb}^{2+}$ in an aqueous solution in the presence of the ligand $\mathrm{H}_{3} \mathbf{B A 3 A}$ depending on $\mathrm{pH}$ at $C\left(\mathrm{H}_{3} \mathbf{B A} \mathbf{A} \mathbf{A}\right)=C\left(\mathrm{~Pb}^{2+}\right)=1 \mathrm{mM}$.

to the higher basicity and the presence of three additional chelating groups. Establishing the potential (change less than $0.2 \mathrm{mV} / \mathrm{min}$ ) for each point of the potentiometric curve took less than 5 minutes, which indirectly confirms the rapid complexation at $25{ }^{\circ} \mathrm{C}$ between $\mathrm{H}_{3} \mathbf{B A} \mathbf{3} \mathbf{A}$ and $\mathrm{Pb}^{2+}$. With regard to the smaller number of donor groups in $\mathrm{H}_{3} \mathbf{B A} \mathbf{A} \mathbf{A}$ compared to other macrocyclic ligands based on cyclone: tetraacetate $\mathrm{H}_{4}$ DOTA $\log \beta\left(\right.$ DOTAPb $\left.^{2-}\right)=22.7^{[6]}$ and tetraamide DOTAM $\left(\right.$ TCMC) $\log \beta\left(\right.$ DOTAMPb $\left.^{2+}\right)>19^{[7]}$ - the obtained value of the constant of complexation with $\mathrm{H}_{3} \mathbf{B A} \mathbf{A} \mathbf{A}$ is not crucially lower, taking into account the rapid formation of the complex.

\section{Investigation of Complex Formation of $\mathrm{H}_{3} \boldsymbol{B} \boldsymbol{A 3} \boldsymbol{A}$ with $\mathrm{Pb}^{2+}$ Cations by NMR Spectroscopy}

${ }^{1} \mathrm{H}$ NMR spectra of the free ligands and then with the addition of $\mathrm{Pb}\left(\mathrm{ClO}_{4}\right)_{2}$ and adjusting the $\mathrm{p} D$ of the solution to a certain value were recorded. The spectra in the presence and in the absence of $\mathrm{Pb}^{2+}$ ion were analyzed to assess the interactions between cation and the ligand $\mathrm{H}_{3} \mathbf{B A} \mathbf{3 A}$.

The proton resonances of $\mathrm{H}_{3} \mathbf{B A} \mathbf{3 A}$ at $\mathrm{p} D=12.4$ corresponded to the deprotonated form of the ligand (Figure 2) in accordance with the potentiometric data. ${ }^{[3]}$ The area of aromatic protons in the ${ }^{1} \mathrm{H}$ NMR spectrum contains one multiplet corresponding to the protons of the benzene ring $\mathrm{H}_{1}$ and $\mathrm{H}_{2}$. In the area of aliphatic protons four broadened singlets corresponding to the macrocyclic protons $\mathrm{H}_{4}, \mathrm{H}_{5}$, $\mathrm{H}_{6}$ and $\mathrm{H}_{7}$, and two singlets of the $\mathrm{CH}_{2}$ groups of acetate substituents $\left(\mathrm{H}_{8}\right.$ and $\left.\mathrm{H}_{10}\right)$ are seen.

Changes in the ${ }^{1} \mathrm{H}$ NMR spectrum observed upon the addition of $\mathrm{Pb}^{2+}$ ion to the $\mathrm{D}_{2} \mathrm{O}$ solution of $\mathrm{H}_{3} \mathbf{B A} \mathbf{A} \mathbf{A}$ demonstrate geminal coupling of the methylene protons belonging to the macrocyclic fragment as well as pendant side-arms. As a result, the seven proton signals of the free ligand $\mathbf{B A} \mathbf{A} \mathbf{A}^{3-}$ split into the twelve proton signals (Figure 2).
The ${ }^{1} \mathrm{H}$ NMR spectra for the $\mathrm{Pb}^{2+}$ complex of BA3A is well resolved that indicate the presence of a single complex in the solution with a rigid structure. The formed coordination bonds of the $\mathrm{Pb}^{2+}$ cation with the donor heteroatoms of the azacrown compounds fix the ligand in space in a certain form, and thus prevent the dynamic processes of transition between different conformations of the macrocycle and reduce its number of degrees of freedom. In this regard, the axial and equatorial protons of the methylene groups become magnetically nonequivalent, and an increased number of signals is observed in the ${ }^{1} \mathrm{H}$ NMR spectrum.

No change in the number of ${ }^{13} \mathrm{C}$ peaks in the NMR spectrum of the ligand $\mathrm{H}_{3} \mathbf{B A} \mathbf{A} \mathbf{A}$ was found upon $\mathrm{Pb}^{2+}$ addition, suggesting no chemically distinct isomers were formed (Figure 3).

In the spectrum of the complex $\mathbf{B A} \mathbf{3} \mathbf{A} \times \mathrm{Pb}^{+2}$, the resonances of the protons of the macrocycle, benzene and pendant arms downfield change under the polarization effect of the metal ion (Table 1). Moreover, the methylene protons $\mathrm{H}_{8}$ and $\mathrm{H}_{10}$ of the side arms exhibit the greatest signal shifts. It can be noted that the protons of the macrocycle are downfield-shifted with the order of $\mathrm{H}_{7}>\mathrm{H}_{4}>\mathrm{H}_{6}>\mathrm{H}_{5}$. Slight shift to a higher frequency field is also observed for $\mathrm{H}_{5}$ protons, due to the diamagnetic through-space shielding effect on the chemical shifts of $\mathrm{H}_{5}$ protons located close to the surrounding carbonyl groups of pendant arms. In this regard, it can be assumed that all heteroatoms of the macrocycle participate in the complexation with the $\mathrm{Pb}^{2+}$ cation.

It is interesting to note that the geminal protons $\mathrm{H}_{8 \mathrm{x}, \mathrm{y}}$ of two opposite acetate groups appear as two doublets, while the methylene protons $\mathrm{H}_{10}$ of the central acetate group appear as a singlet. This can be explained by the fact that the central acetate group is in the symmetry plane, which is perpendicular to the macrocycle, and, therefore, the geminal protons of $\mathrm{H}_{10}$ are magnetically equivalent. In this case, two opposite acetate groups are located above the macrocy- 

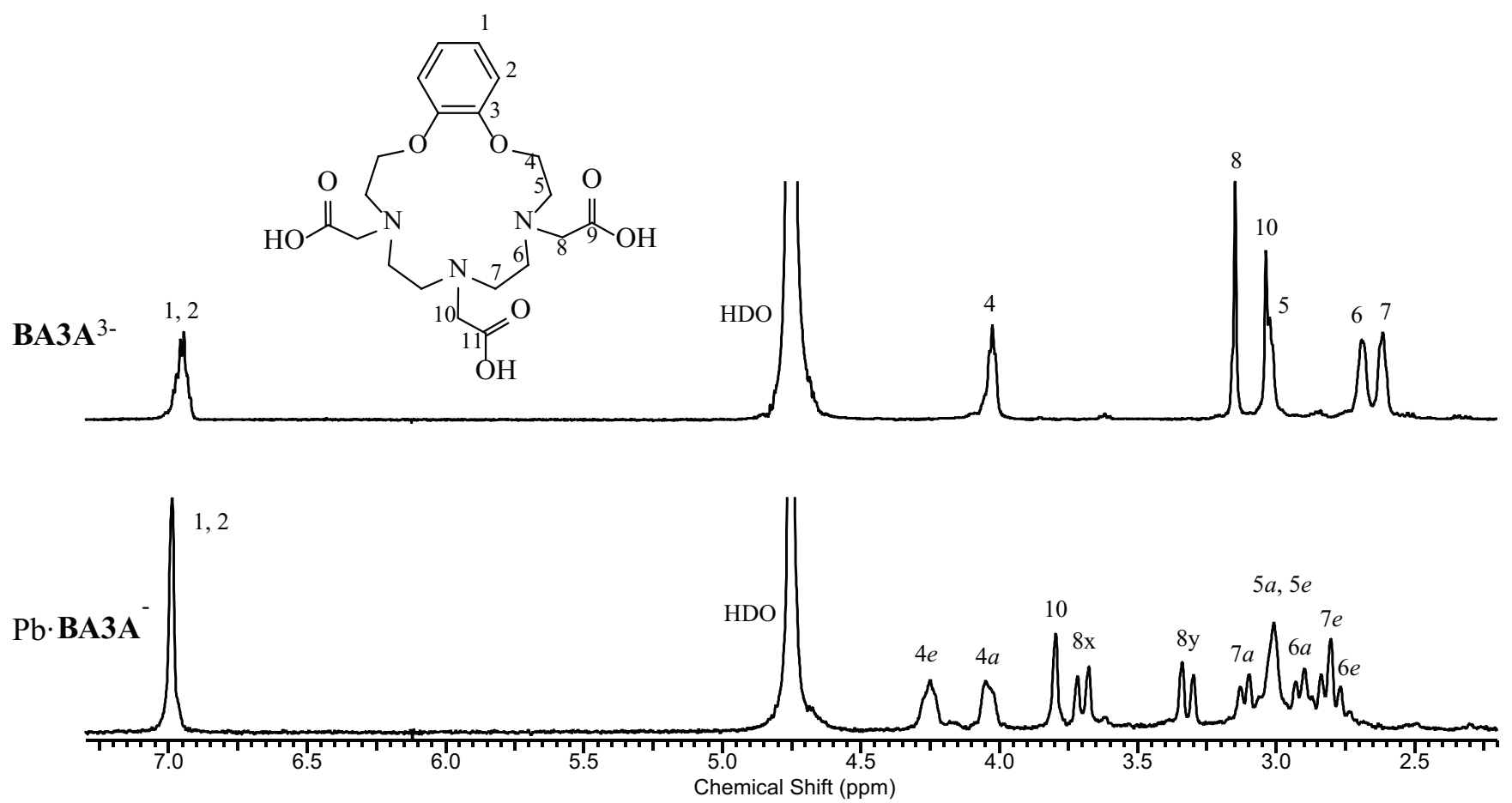

Figure 2. ${ }^{1} \mathrm{H}$ NMR spectra of free $\mathbf{B A 3 A}^{-}(C(\mathrm{~L})=10 \mathrm{MM}, \mathrm{p} D=12.4)$ and in the presence of $\mathrm{Pb}^{2+}(C(\mathrm{~L})=10 \mathrm{MM}, \mathrm{p} D=7.0)$ in $\mathrm{D}_{2} \mathrm{O}$.

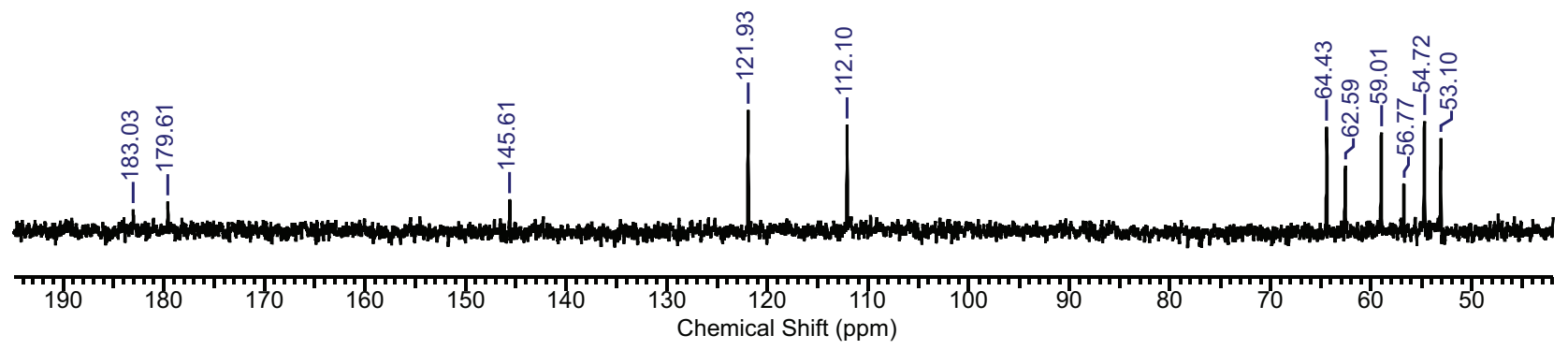

Figure 3. ${ }^{13} \mathrm{C}$ NMR spectrum of $\mathrm{H}_{3} \mathbf{B A 3 A}(C(\mathrm{~L})=10 \mathrm{MM}, \mathrm{p} D=12.4)$ in the presence of $\mathrm{Pb}^{2+}(C(\mathrm{~L})=10 \mathrm{MM}, \mathrm{p} D=7.0)$ in $\mathrm{D}_{2} \mathrm{O}$.

Table 1. Chemical shifts $(\Delta \delta, \mathrm{ppm})$ in ${ }^{1} \mathrm{H}$ NMR spectra of the ligand $\mathrm{H}_{3} \mathbf{B A 3 A}$ and complex $\mathbf{B A 3} \mathbf{A} \times \mathrm{Pb}^{2+}$ in $\mathrm{D}_{2} \mathrm{O}$.

\begin{tabular}{lcc}
\hline & $\mathbf{B A 3 A}^{3-}$ & $\mathbf{B A 3 A} \times \mathrm{Pb}^{+2}$ \\
\hline $\mathrm{H}_{1}$ & 6.94 & $6.99(\Delta \delta=0.05)$ \\
$\mathrm{H}_{2}$ & & $4.05(\Delta \delta=0.03)$ \\
\hline $\mathrm{H}_{4 a}$ & 4.02 & $4.25(\Delta \delta=0.23)$ \\
$\mathrm{H}_{4 e}$ & & $3.01(\Delta \delta=-0.01)$ \\
\hline $\mathrm{H}_{5 a}$ & 3.02 & $2.90(\Delta \delta=0.21)$ \\
$\mathrm{H}_{5 e}$ & & $2.80(\Delta \delta=0.11)$ \\
\hline $\mathrm{H}_{6 a}$ & 2.69 & $3.10(\Delta \delta=0.49)$ \\
$\mathrm{H}_{6 e}$ & & $2.80(\Delta \delta=0.19)$ \\
\hline $\mathrm{H}_{7 a}$ & 2.61 & $3.68(\Delta \delta=0.53)$ \\
$\mathrm{H}_{7 e}$ & & $3.30(\Delta \delta=0.15)$ \\
\hline $\mathrm{H}_{8 \mathrm{x}}$ & 3.15 & $3.80(\Delta \delta=0.76)$ \\
$\mathrm{H}_{8 \mathrm{y}}$ & &
\end{tabular}

clic cavity, coordinating the metal cation. Considering also that the diameter of the $\mathrm{Pb}^{2+}$ cation $(2.40 \AA)$ is larger than the size of the macrocyclic cavity (1.7-2.2 $\AA$ ), it can be concluded that the $\mathrm{Pb}^{2+}$ cation is fixed by three acetate groups above the macrocycle cavity, and the resulting $\mathbf{B A} \mathbf{3} \mathbf{A} \times \mathrm{Pb}^{+2}$ complex possesses $\mathrm{C}_{\mathrm{s}}$ symmetry.

\section{Radiolabeling Efficiency}

Since the obtained complexation constants are sufficiently high, it is expedient to radiolabel ligand with lead cation and study its stability in biologically relevant media for use in radiopharmaceuticals. In this work, ${ }^{210} \mathrm{~Pb}$ radionuclide isolated from a solution of ${ }^{226} \mathrm{Ra}$ was used as a radioactive label. The activity of ${ }^{210} \mathrm{~Pb}(4-5 \mathrm{kBq}$, $0.4 \mu \mathrm{M})$ simulated trace amounts of the ${ }^{212} \mathrm{~Pb}$ cation (1-10 MBq, up to $1 \mathrm{nM}$ ) used for therapy. The preparation of the labelled compound at different concentrations of the ligand was carried out at $\mathrm{pH} 5.5-6$ according to the previously obtained distribution of complex forms versus $\mathrm{pH}$ : at this $\mathrm{pH}$, the main complex form is $\mathbf{P b \mathbf { B A }} \mathbf{A} \mathbf{A}^{-}$(Figure 1). 
Table 2. Radiolabeling yield of $\left[{ }^{210} \mathrm{~Pb}\right] \mathrm{PbBA3A}$ with varied ligand's concentration.

\begin{tabular}{rcccccc}
\hline$C\left(\mathrm{H}_{3} \mathbf{B A 3 A}\right), \mu \mathrm{M}$ & 10 & 20 & 50 & 100 & 200 & 500 \\
\hline Radiolabeling yield, $\%$ & $9 \pm 5$ & $70 \pm 7$ & $92 \pm 5$ & $99 \pm 5$ & $99 \pm 5$ & $99 \pm 5$ \\
\hline
\end{tabular}

To obtain the complex as a component of the radiopharmaceuticals at a given $\mathrm{pH}$, biologically acceptable buffer systems are used. In this case, we tested solutions of MES, PBS, and NaOAc. For quality control, thin layer chromatography combined with digital radiography and measurement on a gamma spectrometer was used. According to the results obtained, MES binds the ${ }^{210} \mathrm{~Pb}$ cation by $20 \%$, while PBS and NaOAc do not affect the formation of $\left[{ }^{210} \mathrm{~Pb}\right] \mathrm{PbBA} \mathbf{B A}$; therefore, the latter two systems can be used to obtain this labelled compound. The study of the ligand's concentration required for the complete binding of the radionuclide into the complex was carried out in the presence of NaOAc. According to the obtained values (Table 2), more than $95 \%$ of the cation is chelated with a ligand concentration above $100 \mu \mathrm{M}$.

It is important to note that all the obtained results on radiochemical yields were obtained immediately after mixing the reagents at room temperature within 1-5 minutes. For comparison, the synthesis at a ligand concentration of $20 \mu \mathrm{M}$ was carried out by heating up to $90^{\circ} \mathrm{C}$ for $30 \mathrm{~min}$ utes; the reaction yield did not differ from that obtained at room temperature. Thus, it has been shown that $\mathrm{H}_{3} \mathbf{B A} \mathbf{3 A}$ binds lead cations, as well as copper and zinc cations, ${ }^{[3]}$ rapidly and without additional heating. This fact can be explained due to the larger size of the macrocyclic cavity than that of the cyclene-based ligands, the chelation of which requires elevated temperatures ( $\mathrm{H}_{4}$ DOTA, DOTAM). The larger size of the $\mathrm{H}_{3} \mathbf{B A} \mathbf{A} \mathbf{A}$ cavity reduces steric hindrances for deprotonation of the ligand and the concomitant coordination of the cation, ${ }^{[8,9]}$ which leads to the absence of the need for additional heating to facilitate the preparation of the labelled compound.

\section{Stability of $\left[{ }^{210} \mathrm{~Pb}\right] \mathrm{Pb} \boldsymbol{B} \boldsymbol{A} \mathbf{3}$}

Due to the presence of a large number of chelating agents in vivo, as well as cations of microelements, dissociation and release of the radionuclide cation from the complex compound with the chelator regardless of the vector molecule is possible, which can lead to the accumulation of radioactivity in healthy organs and tissues and their irradiation by alpha and beta particles, in the case of ${ }^{212} \mathrm{~Pb} /{ }^{212} \mathrm{Bi}$, which are highly toxic. Therefore, to assess the behavior of the complex in the organism's environment, the stability of the complex was studied in the presence of serum proteins as competing chelators and in the model aqueous solutions of $\mathrm{Ca}^{2+}, \mathrm{Mg}^{2+}, \mathrm{Fe}^{3+}$, $\mathrm{Zn}^{2+}$, and $\mathrm{Cu}^{2+}$ cations, and isotonic $\mathrm{NaCl}$ solution.

Firstly, we studied the possibility of dissociation of the complex compound obtained at the lowest concentration of $\mathrm{H}_{3} \mathbf{B A 3 A} 100 \mu \mathrm{M}$ according to Table 2. However, due to dilution of the solution with a ninefold excess of serum, the final content of the ligand $10 \mu \mathrm{M}$ is insufficient to effectively hold the cation in the complex: a third of the complex dissociates in 4 hours, and in 1 day only about $20 \%$ remains in the form of the initial labeled compound (Figure 4). In the case of ${ }^{212} \mathrm{~Pb}$ with a half-life of $10 \mathrm{~h}$, it is preferable that there is no dissociation for at least 48 hours - during this time, the activity of the introduced radionuclide decreases by a factor of $\sim 30(\sim 5$ half-lives, a decrease in activity by a factor of $2^{5}=32$ ).

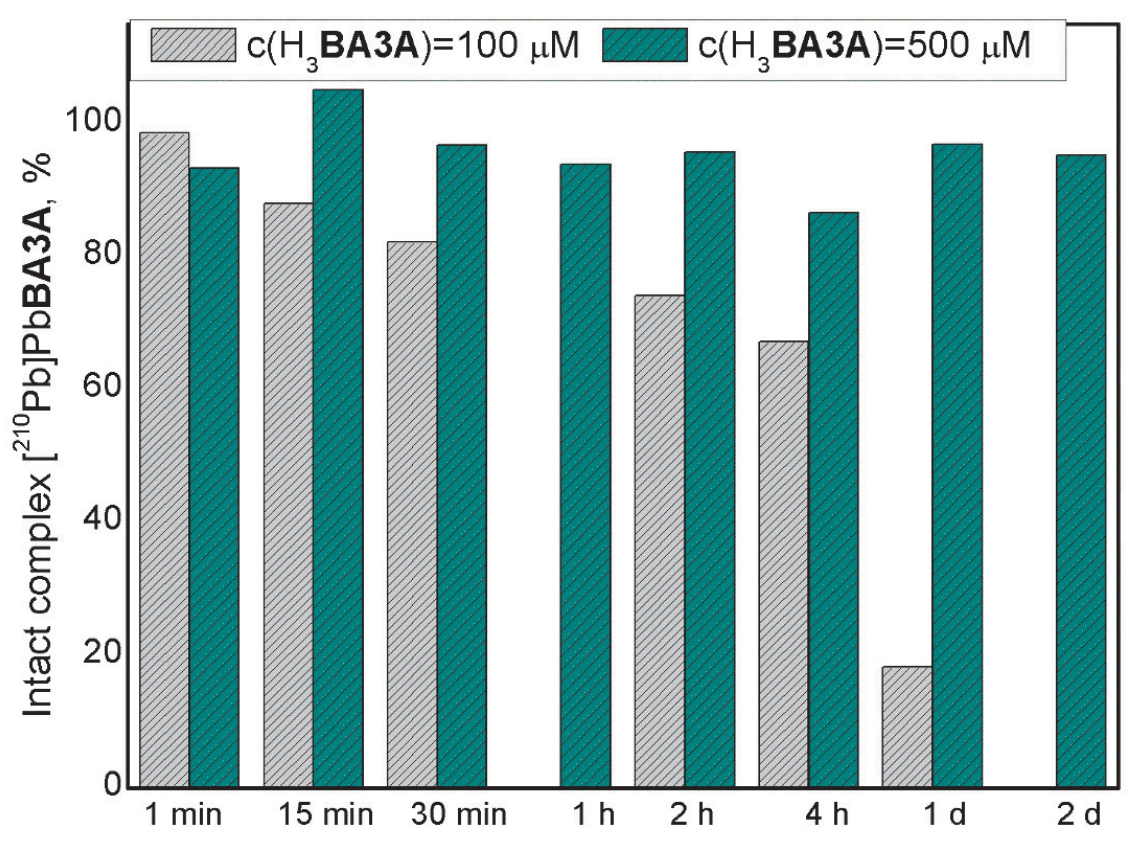

Figure 4. Dissociation of $\left[{ }^{210} \mathrm{~Pb}\right] \mathrm{PbBA} 3 \mathrm{~A}$ in the presence of serum proteins. 
Table 3. Part of ${ }^{210} \mathrm{~Pb}$ in the complex with $\mathrm{H}_{3} \mathbf{B A 3 A}$.

\begin{tabular}{lcccccc}
\hline \multicolumn{1}{c}{ cation } & $\mathrm{Ca}^{2+}$ & $\mathrm{Mg}^{2+}$ & $\mathrm{Zn}^{2+}$ & $\mathrm{Cu}^{2+}$ & $\mathrm{Fe}^{3+}$ & $\mathrm{NaCl}^{2}$ \\
\hline 1 hour & $99 \pm 1$ & $99 \pm 1$ & 100 & $99 \pm 1$ & $99 \pm 1$ & $99 \pm 1$ \\
1 day & 100 & 100 & $99 \pm 1$ & $99 \pm 1$ & 100 & $99 \pm 1$ \\
\hline
\end{tabular}

For comparison, we made a similar experiment with an increase of the concentration of the ligand to $500 \mu \mathrm{M}$, so that when diluted with serum by 10 times, the final concentration of the ligand was $50 \mu \mathrm{M}$. This turned out to be enough for no release of the radionuclide from the complex at leased within two days of incubation. This fact may indicate a rapid chelation of the released cation even in the presence of competing agents. Under the same conditions, in the presence of millimolar amounts of cations of microelements, dissociation of the $\left[{ }^{210} \mathrm{~Pb}\right] \mathrm{PbBA} \mathbf{3 A}$ complex is not observed both within 1 hour and 1 day (Table 3).

\section{Conclusions}

Benzo-15-azacrown-5 triacetate can be used to bind lead radionuclide as a component of a targeted radiopharmaceutical, according to the obtained results. The complex formed has a rigid structure in an aqueous solution, is highly stable not only thermodynamically, but also in the presence of competing agents. Moreover, the complex formation occurs quantitatively at room temperature within several minutes, which makes its additional purification from unbound radionuclide unnecessary, and also, what is extremely important, prevents the loss of activity at the stage of radiopharmaceuticals synthesis.

Thus, this complex can be used to obtain even immunotherapeutic pharmaceuticals based on antibodies, which are especially sensitive to heat, and radionuclide
${ }^{212} \mathrm{~Pb}$ as an in vivo generator of alpha-emitting ${ }^{212} \mathrm{Bi}$. Consequently, further study of the complexation of $\mathrm{H}_{3} \mathbf{B A} \mathbf{A} \mathbf{A}$ with the $\mathrm{Bi}^{3+}$ cation seems to be promising in order to predict the behavior of the complex after the transformation of ${ }^{212} \mathrm{~Pb}$ into ${ }^{212} \mathrm{Bi}$.

Acknowledgements. This work was supported by the Russian Science Foundation grant No. 18-73-10035.

\section{References}

1. Nelson B.J.B., Andersson J.D., Wuest F. Pharmaceutics 2021, 13, 49. doi 10.3390/pharmaceutics13010049

2. Egorova B.V., Fedorova O.A., Kalmykov S.N. Uspekhi Khimii [Russ. Chem. Rev.] 2019, 88, 901-924. doi 10.1070/RCR4890

3. Aleshin G.Yu., Egorova B.V., Priselkova A.B. et al. Dalton Trans. 2020, 49, 6249-6258. doi 10.1039/d0dt00645a

4. Eichrom Technologies, Analytical procedures, Lead-210 and Polonium-210 in water, 2014.

5. Zubenko A.D., Egorova B.V., Zamurueva L.S., Kalmykov S.N., Fedorova O.A. Mendeleev Commun. 2021, 31, 194-196. doi 10.1016/j.mencom.2021.03.016

6. Liu S., Edwards S.D. Bioconjug. Chem. 2001, 12, 7-34. doi $10.1021 / \mathrm{bc} 000070 \mathrm{v}$

7. Maumela H., Hancock R.D., Carlton L., et al. J. Am. Chem. Soc. 1995, 117, 6698-6707. doi 10.1021/ja00130a008

8. Jang Y.H., Blanco M., Dasgupta S., et al. J. Am. Chem. Soc. 1999, 121, 6142-6151. doi 10.1021/ja983706q

9. Moreau J., Guillon E., Pierrard J.C., et al. Chem. Eur. J. 2004, 10, 5218-5232. doi 10.1002/chem.200400006 